Illinois State University

ISU ReD: Research and eData

Theses and Dissertations

7-22-2019

\title{
Manifest Destiny Continued: The Reification and Colonization of Time
}

Blake Reno

Illinois State University, booreno62@gmail.com

Follow this and additional works at: https://ir.library.illinoisstate.edu/etd

Part of the English Language and Literature Commons

\section{Recommended Citation}

Reno, Blake, "Manifest Destiny Continued: The Reification and Colonization of Time" (2019). Theses and Dissertations. 1163.

https://ir.library.illinoisstate.edu/etd/1163

This Thesis is brought to you for free and open access by ISU ReD: Research and eData. It has been accepted for inclusion in Theses and Dissertations by an authorized administrator of ISU ReD: Research and eData. For more information, please contact ISUReD@ilstu.edu. 


\section{MANIFEST DESTINY CONTINUED: THE REIFICATION \\ AND COLONIZATION OF TIME}

\section{BLAKE RENO}

\section{Pages}

With the end of the settlement of what became the continental United States, capitalism and imperialism by nature needed to continue in their growth. In the late $19^{\text {th }}$ and early $20^{\text {th }}$ century up through World War I, history and the time of laborers were the sites of expansion for capitalism. There was a realization that public relations and journalism were in essence writing history as it was happening, and capitalists took note and moved into adjusting these spheres in their favor. In addition, capitalists began attempting to expand their influence over the time of their laborers in order to increase production and the growth of capital.

KEYWORDS: Marx, Lukacs, time, Dos Passos, Pynchon, Scientific Management 


\title{
MANIFEST DESTINY CONTINUED: THE REIFICATION \\ AND COLONIZATION OF TIME
}

\author{
BLAKE RENO
}

A Thesis Submitted in Partial

Fulfillment of the Requirements for the Degree of

\section{MASTER OF SCIENCE}

Department of English

\section{ILLINOIS STATE UNIVERSITY}


Copyright 2019 Blake Reno 


\section{MANIFEST DESTINY CONTINUED: THE REIFICATION \\ AND COLONIZATION OF TIME}

BLAKE RENO

COMMITTEE MEMBERS:

Christopher Breu, Chair

Paul Ugor 


\section{ACKNOWLEDGMENTS}

This project would not have been possible without Christopher Breu, who not only served as chair for this thesis, but also supported me in my studies for many years prior. I would also like to thank Robert McLaughlin, who intended to serve as an advisor on this project, but circumstances did not allow him to finish this role. Thanks to Paul Ugor for stepping in and being able to advise for this project on short notice and providing much guidance for the project.

B. $\mathrm{R}$. 


\section{CONTENTS}

Page

ACKNOWLEDGMENTS

$\begin{array}{ll}\text { INTRODUCTION } & 1\end{array}$

CHAPTER I: THE “AD”-VENT OF REIFICATION OF HISTORY 15

CHAPTER II: LABORING UNDER TIME

$\begin{array}{ll}\text { EPILOGUE } & 50\end{array}$

WORKS CITED 


\section{INTRODUCTION}

While Ernesto Laclau serves as one of the figureheads of "post-Marxist" thought, I believe his thinking to be crucial to understanding what I wish to accomplish with this work. My invocation of Laclau may seem contradictory considering I will be utilizing Marx and Lukács later in this text but bear with me. In Laclau's essay, "New Reflections on the Revolution of Our Time," he lays out an attempt at deconstructing the logic of Marx's dialectic as far as the antagonistic (and therefore inherently dialectical) relationship between the capitalist and the laborer. It is with a quote from this section that we begin our discussion:

$\ldots$ if the constitutive nature of antagonism is taken for granted, the mode of questioning of the social is completely modified, since contingency radically penetrates the very identity of the social agents. The two antagonistic forces [(the laborer and the capitalist)] are not the expression of a deeper objective movement that would include both of them; and the course of history cannot be explained in terms of the essential 'objectivity' of either. (22)

This is essentially a summary of the first bit of Laclau's essay in which he attempts to debunk the objectivity of the "capitalist" and "laborer" as two inherently antagonistic beings and since he argues that Marx takes this antagonism for granted, there is no way to establish a history of class struggle and no way to realize a static idea of a capitalist or the static idea of a laborer and that that all capitalists and laborers are part of one singular objective "structure" that has been realized. Laclau continues:

... this is the point where Marxist analysis becomes unacceptable. If, as we have seen, the very antagonism between worker and capitalist is not internal to the relations of production, but is established between the relations of production and an identity external 
to them, then the modes of relation with that 'outside' cannot be an automatic effect of the logic of accumulation. (author's italics) (24)

And this is where I find the ground with which to begin examining Marx himself. Marx took the time to examine one of the most objective of all things: time.

While he doesn't take a scientific look at the concept of time, he makes it clear that labor and its value have an inherent dependence on time, because if time was unlimited, the value extracted from laborers would be much lower. Part of the reason the commodity exists at all is the fact that people only have a limited amount of time in which to exist, so often things are purchased from someone else with the paraphernalia necessary to create a product so one does not have to use their labor-power, that is, their time (which is what gives labor its value in the first place) in order to produce it themselves. Essentially, time itself is a limited resource for all parties involved and this is where the antagonism exists between the capitalist and the worker.

Time as a limited resource is both internal and external to the labor process. It is internal to the labor process in that time is consumed during labor, in the production of the commodity, but is also external in that the laborer's time exists outside of the labor process as well. This is the inherent antagonism in the relationship between laborer and capitalist. We see wars of all sorts fought over limited or hard to acquire resources, and the war that happens on a daily basis is the war between the capitalist and the laborer over the laborer's own time. We can understand this as a war (within reason) in the way Marx examines the working day in Capital Volume I: "Although the working day is not a fixed but a fluid quantity, it can, on the other hand, vary only within certain limits. The minimum limit, however, cannot be determined. ... On the other hand, the working day does have a maximum limit" (341). Obviously, the absolute maximum limit is 24 hours, although Marx theorizes a maximum according to the needs of the laborer with the 
caveat that "... these limiting conditions are of a very elastic nature, and allow a tremendous amount of latitude. So we find working days of many different lengths, of $8,10,12,14,16$, and 18 hours" (341). While Newtonian time itself is inelastic and inflexible, the working day is very flexible. Marx establishes that the laborer demands that they be allowed to at least have the ability to maintain their health and in the exchange of commodities, the commodity of their labor must be able to remain constant as per the agreement of the exchange of labor-value (343).

As stated earlier, we can think of a person's time as a vastly limited resource and compare it with other natural resources that occur. Just like capitalism looks to exploit natural resources to their fullest, and as we know in our contemporary period, have no issue with pushing the planet itself to its limit, capitalism looks to exploit the time of its laborers in order to create surplus-value. In historicizing this and creating a geographical center for which we can discuss this, we can start with Marx's discussion of slavery in the United States:

But as soon as peoples whose production still moves within the lower forms of slavelabour ... are drawn into a world market dominated by the capitalist mode of production, whereby the sale of their products for export develops into their principal interest, the civilized horrors of over-work are grafted onto the barbaric horrors of slavery, serfdom etc. Hence the Negro labour in the southern states of the American Union preserved a moderately patriarchal character as long as production was chiefly directed to the satisfaction of immediate local requirements. But in proportion as the export of cotton became of vital interest to those states, the over-working of the Negro, and sometimes the consumption of his life in seven years of labour, became a factor in a calculated and calculating system. It was no longer a question of obtaining from him a certain quantity 
of useful products, but rather of the production of surplus-value itself. (emphasis mine)

I wish for this quote to mark a transition in my argument. It sets a historical context for the argument I wish to put forth and also contextualizes the argument within Marxist theory. As Marx himself establishes in the quote, once those states realized how much value cotton had, it became not about the amount or quantity of production, but extraction of surplus-value. And by extension, it became about consuming all of the useful years of labor in his life. The antagonism in capitalism is not about labor, but about time.

I will return to the above quote later when it comes time to discuss the historical context for the main breadth of establishing when capitalism became more about exploiting time than about exploiting labor. Marx was correct in his theorizing that the labor process and the production of surplus-value that results from that process turns the laborer into an object separate from the commodity they produce and in short, reifies them. However, this does not necessarily comply with how he formulates how over-working and the realization that surplus-value cannot exist without surplus-labor, which itself cannot be realized without the laborer contributing surplus time to the capitalist. This is time that could be used elsewhere in the laborer's life for either rest, food, or labor that benefits the laborer directly.

Georg Lukács, who wrote more in depth about the concept of reification as part of the labor process, includes time in his conception of how the laborer is reified:

Here we need only establish that labour, abstract, equal, comparable labour, measurable with increasing precision according to the time socially necessary for its accomplishment, the labour of the capitalist division of labour existing both as the presupposition and the product of capitalist production, is born only in the course of the development of the 
capitalist system. Only then does it become a category of society influencing decisively the objective form of things and people in the society thus emerging, their relation to nature and the possible relations of men to each other. (emphasis mine) (87-88)

Lukács sees this objectification or reification as a social relationship. However, forming any sort of social relationship takes time, whether it is between the laborer and capitalist or laborers with each other. These relations are all necessarily reified in Lukács' examination of the capitalist system of production. That said, I wish to draw attention to how the laborer needs to have the time necessary to create these social relations. But, as Marx theorized was possible with a flexible work day, social relations are rendered impossible by the control of the working day by the capitalist. As Marx himself writes, "Capitalist production therefore drives, by its inherent nature, towards the appropriation of labour throughout the whole of the 24 hours in the day" (367). Certainly, Marx may be referring to commodity production occurring all 24 hours of each day, but he goes on to elaborate that capitalism, indeed, looks to move beyond a reasonable working day.

Marx establishes that time outside of the working day is necessary for a person to grow and be able to reproduce their labor on a daily basis: "Time for education, for intellectual development, for the fulfillment of social functions, for social intercourse, for the free play of the vital forces of his body and his mind, even the rest time of Sunday. .." (375). And Marx connects the laborer's own use of time directly with labor-time:

Surplus labor and necessary labor are mingled together. I can therefore express the same relation by saying that in every minute the worker works 30 seconds for himself and 30 seconds for the capitalist, etc.... The necessary labour which the Wallachian peasant performs for his own maintenance is distinctly marked off from his surplus labour on 
behalf of the boyar. The one he does on his own field, the other on the seignorial estate. Both parts of the labour-time thus exist independently, side by side with each other. (emphasis mine) (346)

If we combine the quote from Lukács and these Marx quotes we can fully grasp that time is an offset thing separate from the laborer in two quantities. While the laborer is reified in how he is separated and alienated from the commodity they produce, we must understand that by extension of this dynamic and in combination with Lukács' theorizing that the labor is being more and more precisely measured by the time necessary for its viability and how Marx theorized both types of the laborer's labor-time and their independent existence, that time itself is reified separately from the laborer. This will be explained in greater detail in the second chapter.

While Laclau's main issue with Marx's theorizing was the lack of the objective nature of the antagonism between capitalist and the laborer, Newtonian time is inherently objective. There is no way to theorize a labor-process outside of time and time is where much of this antagonism comes from because the most important part of surplus-value is not necessarily the labor, but that the most efficient way to extract surplus-value is through surplus-labor. It is not the labor itself that is surplus here, but the time concept of the labor: that the labor is done faster (that is, more labor is performed over time) or that the laborer spends more time performing labor at the usual rate. The fact that time exists as a separate quantity is what allows capitalism to pursue it as if it were a natural resource. As Marx states:

But in its blind and measureless drive, its insatiable appetite for surplus labour, capital oversteps not only the moral but even the physical limits of the working day. It usurps the time for growth, development and healthy maintenance of the body. It steals the time required for the consumption of fresh air and sunlight. It haggles over the meal-times, 
where possible incorporating them into the production process itself . . Capital asks no questions about the length of life of labour-power. What interests it is purely and simply the maximum of labour-power that can be set in motion in a working day. (375-76) And this quote demonstrates that in its goal for surplus-value, capitalism wants to consume as much of the laborer's time as possible. Marx demonstrates this in many ways throughout his studies of various factories and companies in Europe, however, I wish to focus this text on how this phenomenon has occurred in the United States. To do so, we must begin by historicizing.

When speaking of time and historicizing capitalism in the United States, the most logical place to begin is with Frederick Winslow Taylor, the creator of Scientific Management. While he published the summation of his thinking and techniques in 1911 with The Principles of Scientific Management, we must understand that these thoughts had been developed by him since 1878, when he obtained a job at Midvale Steel Works (where he would also put some of his ideas to practice once he was put into a position where he could manage laborers).

Somewhat ironically, he begins The Principles of Scientific Management with a quote from Theodore Roosevelt, who is commonly thought of in our time as a "progressive" politician for his own time. This quote, "The conservation of our national resources is only preliminary to the larger question of national efficiency" (5), demonstrates that while we think of "Teddy" Roosevelt today as a conservationist and a "trust-buster," this may not entirely be the case, as this quote demonstrates. In order to "conserve" resources, we must use them, but in an efficient manner. Taylor reads this quote further for us in order to discuss the lack of efficiency of laborpower:

We can see our forests vanishing, our water-powers going to waste, our soil being carried by floods into the sea; and the end of our coal and iron is in sight. But our larger wastes 
of human effort, which go on every day through such of our acts as are blundering, illdirected, or inefficient, and which Mr. Roosevelt refers to as a lack of "national efficiency," are less visible, less tangible, and are but vaguely appreciated. (5) Here, Taylor does some of the work for us, he compares time (even though he does not conceptualize it as such) directly with natural resources and even theorizes that "wasting" time is a "larger" waste than an inefficient use of natural resources. We see this attitude prevailing even in contemporary or "late" capitalism: that management within businesses are more concerned with how employees use their time (that is, time that the company has taken for themselves from the employee/laborer) more than abusing and destroying nature and natural resources.

For a moment, I wish to historicize another concept, that of "manifest destiny." While this seems unrelated to Taylor's ideas and attitude, I must elaborate on manifest destiny before the connection becomes clear. The term was most widely used before the American Civil War to denote an attitude that Americans had something special about them that meant it was their "destiny" to make the rest of the continent in their image. This phrase lost its use during the American Civil War, as the war was fought over slavery and if it was going to be part of the idea of America going forward or if it was to be eliminated entirely. Thus, it was because the idea of "America" and what its people stood for was in flux during that time that the term's use faded.

However, the term reappeared in high-level politics around the turn of the $20^{\text {th }}$ century. We can see the term used in the Republican platform for the 1892 presidential election, as they stated, "We reaffirm our approval of the Monroe doctrine, and believe in the achievement of the manifest destiny of the republic in its broadest sense" (Lesueur 245). That said, historian Frederick Merck, in his book about the concept of manifest destiny does note that the term "manifest destiny" as used in the quote, “. . was in no way defined, however, and probably 
meant to innocent readers almost nothing at all" (241). That said, Merck also discusses the political state of the country the very same year the phrase reappeared:

The Populists, in their famous platform of 1892, recommended among other things . . . an eight-hour working day ... Republicans recommended protective tariffs, bimetallism, and more stringent laws to exclude criminals, paupers, and contract labor. No party recommended overseas expansion as a restorative or cure [for the deepening economic depression]. (emphasis mine) (241)

Merck does mention the earlier quote about manifest destiny as a possible exclusion to no party recommending overseas expansion. We can also see here that Populists had ideas for putting a limit on the time that capitalism can take from its laborers. However, we also see Republican ideas aligning with capitalism's hopes to exclude people (particularly those who are most at the mercy of capitalism) from being able to exercise their rights and how these ideas were about to collide (this is one of the major themes within Thomas Pynchon's novel, Against the Day, which I will discuss in chapter II).

The most incisive quote that Merck provides us is one that theorizes the manifest destiny at the turn of the century and connects it to imperialism:

The imperialism of the 1890's is regarded by some historians as a variant merely of Manifest Destiny of the 1840 's. This is an error. It was the antithesis of Manifest Destiny. Manifest Destiny was continentalism. It meant absorption of North America. It found its inspiration in states' rights. It envisaged the elevation of neighboring peoples to equal statehood and to all the rights and privileges which that guaranteed. Expansionism in 1899 was insular and imperialistic. Its inspiration was a nationalism of a sort. It involved the reduction of distant peoples to a state of colonialism. (emphasis mine) (256-57) 
If we compare these last two quotes, they are concerned with an "othering" of particular sets of people. On one hand, it is criminals, the poor, and contract labor and on the other hand, it is distant people, or as Merck alternatively describes, "a people not capable of rising to statehood" (257). While exclusion of the poor was part of the 1892 Republican platform for the presidential election, an election they would lose, they would proceed to take the office in 1896 with the election of Benjamin Harrison and continue to hold the office until the election of Woodrow Wilson in 1912, who was primarily elected to keep us out of World War I, which we know did not happen. Thus, Republicans ran the country during this period of imperialism. However, the country was effectively divided on the annexation of conquered territories.

This created a turn in American culture with regards to manifest destiny. Turning to Merck again, he explains that "After the Spanish-American War ... expansionism lost its attractiveness. ... Too much swallowing [of other people] had, as usual, the effect of surfeit, weariness, and lethargy" (emphasis mine) (257). With the end of this quote, we must be reminded of Taylor's response to Roosevelt's quote. While outward expansion became unfavorable, it became necessary to "other" those who did not contribute enough to the country, that is, as per the Republican 1892 platform, "criminals, paupers, and contract labor." So while manifest destiny as an attitude toward external peoples and land was not favored by the country, that attitude was able to be turned inward. The spirit of manifest destiny was not much different from capitalism, as I quoted Marx earlier in how capitalism dealt with time, "But in its blind and measureless drive, its insatiable appetite for surplus labour, capital oversteps not only the moral but even the physical limits of the working day. It usurps the time for growth, development and healthy maintenance of the body" (375). The Republicans who "othered" a particular set of American people and capitalism together joined in attitudes and set forth to essentially colonize 
their own people indirectly. As we discussed earlier, the main antagonism between laborers and capitalists we are discussing here is about time. And if we examine the essentially equal attitudes of Roosevelt (who served as a Republican president from 1901-1909 and did not become a Progressive "Bull Moose" until 1912), Taylor, and what Merck had stated about the country entering a state of "lethargy" due to expansion, we can understand that several powerful parties, and on some level, the country's populace itself, was aware of this lethargy. However, those in power (Taylor and Roosevelt, for example) were looking to eliminate that in the population and, naturally, those under the thumb of capitalism were most vulnerable. In short, time had been reified in the laborer, and manifest destiny, with it being denied of outward expansion, turned inward to colonize the time of laborers.

Time had to be the thing to be colonized, and if it was done overtly, as Marx describes in the earlier quote when he discusses slavery in the United States, the resistance to it would have been much stronger. But because the "lack of efficiency" in use of time was, as Taylor discusses, "less visible" and "less tangible," it was easier for time to be manipulated than sheer laborpower. This attitude that capitalism took towards labor in this period was not unlike what Marx described about how the labor of slavery worked in that it was more about the consumption of the laborer's life in however many years of labor they could extract from them, as after the laborer could no longer work for whatever reason, there was no more surplus-value that could be extracted from the laborer.

Also, at this time, capitalism became conscious of a battle for the public's opinion. That is, if working conditions were to come to light, then resistance would be stronger. That is not to say that unionization did not occur as a response to these developments. Groups such as the American Federation of Labor and the Industrial Workers of the World attempted to fight back 
against these conditions, but the war against colonization of time essentially became a war about public opinion between the laborer's explaining their plight and capitalists essentially vilifying anyone who stood against them. Even Upton Sinclair's famous novel, The Jungle, could not sway people towards socialism and against exploitation of laborers. While the public did respond to the health and sanitation violations of the industry, capitalism had won, as this reaction made it clear that the public was more concerned about their own ability to stave off illness and be able to work at all than being concerned about the conditions of labor and exploitation of time that many laborers toiled under. Thus, this is what the novel is more remembered for than for its endorsement of socialism and workers' rights.

When we look at American Progress by John Gast, we see the Americans moving right to left, from the light in order to spread the light into the darkness of the country. While this is exemplary of how Americans treated native history, effectively thinking of it as non-history, erasing it and replacing it with their own history. This was part of the goal of capitalists in the early $20^{\text {th }}$ century in the public relations war and this idea actually helps make Laclau's point about the inability to find one singular historical line of class struggle, as capitalism has so effectively divided the class struggle geographically and historically.

This division is part of John Dos Passos' USA trilogy. With its "Newsreel" and "Camera Eye" sections laying against the narratives of the characters of the novel, we can see the conflict between many of the characters and how they are exploited by capitalists and how their history is effectively lost when we realize the "Newsreel" is what the general public was taking in as far as what was going on both at home and abroad. Then, the "Camera Eye" sections represent this half human, half inorganic stream of consciousness that is a running together of a nameless memory 
and the endless production and reproduction of the boom brought about by the change in management techniques in various industries.

By contrast, the trilogy also covers the stories of a few fictional capitalists, whose influence starts small within their own chapters, but eventually you begin to see and hear about them throughout the chapters of other fictional people who are much less fortunate in their treatment from capitalism and we begin to understand that in what was supposed to be the land of the free, where anyone should be able to make their own way, we see how these people with big dreams and how those who are able to put themselves in powerful positions are actually able to control not only the fates of those less fortunate, but are able to control public opinion in the present, and what eventually becomes history itself.

While Dos Passos wrote about the early $20^{\text {th }}$ century from soon after, and his narration, as I will discuss, illustrates both a closeness and a distance. The other novel I wish to examine in this study is Thomas Pynchon's Against the Day. Published 76 years after the publication of The $42^{\text {nd }}$ Parallel, the first novel of Dos Passos' trilogy, Against the Day examines the same time period, but demonstrates the relationship between capitalists and laborers as much more antagonistic, even detailing much of the opposition to exploitation of workers as anarchistic.

Against the Day also explains how capitalists attempted and failed to exploit time in other ways, using explicitly scientific means (think Tesla and Edison), but eventually found a way to reify and colonize the time of laborers. However, in his usual form, Pynchon does hint at ways to oppose this exploitation and that anarchy and individual choice can never truly be eliminated, but that capitalism is attempting to limit choice with every move it makes towards becoming more powerful in both the national and the global sphere. 
My goal in examining these novels is to demonstrate that this evolution in capitalism, its ability to reify and colonize the time of the laborer, is something that developed both as a result of the evolution of capitalism and how it covertly found a way to exploit laborers without bringing attention to the general public by both limiting the power of the individual and by figuring out that it could not only influence the creation and writing of public opinion, but create it in their own image. This is not only a process that has developed over time, but is more apparent in our present day than it was even then, when this sort of exploitation was in its infancy. Ultimately, I wish for these processes to be able to give us new avenues with which to discuss the ways in which capitalism is exploitative not only abroad but within the United States. 


\section{CHAPTER I: THE “AD”-VENT OF REIFICATION OF HISTORY}

In Big Bill's section of The $42^{\text {nd }}$ Parallel, Dos Passos writes that "When he married he went to live in Fort McDermitt built in the old days against the Indians, abandoned now that there was no more frontier" (113). This is an ironic statement considering that the United States government and capitalism found a new frontier and whether or not William Dudley "Big Bill" Haywood realized it when he was attempting to impede capitalism's progress, he was impeding an imperial march on the frontier that is time itself.

Within the USA trilogy, Dos Passos historically diagnoses a myriad of problems with the evolution of the goals of the political economy of the United States. He witnessed and wrote about a very short time after it happened. The temporal proximity of his writing to the events he describes both "fictitiously" and "historically" allow for a more incisive look into the period's own temporal phenomena which gives us the ability to examine 1910-1930 and American movements both physical and temporal, individual and collective, with much more aplomb. As Michael Gold wrote in The English Journal between the publication of Nineteen Nineteen and The Big Money, "What we have now is a cross-section of American humanity which, as much as any history, gives the authentic inside facts of the past twenty years" (96).

Of course, part of what Dos Passos sets out to reveal to the reader is just how inauthentic (to use Gold's terminology) the most commonly consumed conceptions of history were and still are. Part of what the trilogy documents, and what I wish to bring out with this chapter, is that during this period capitalism and those in power in the United States aimed to reify and produce their own history and to create a history that could be consumed by the masses next to other products that were made plenty by the industrial revolution prior to the period that Dos Passos surveys. 
First, we must frame the trilogy itself as a temporal object, both the actual novels as artifacts and the story itself as abstract artifact. On a base level, we can look to Claude-Edmonde Magny in his essay "Time in Dos Passos," who summarizes the temporality of the trilogy's innards thusly: "Dos Passos' characters do not have their own inner rhythm; its place is taken by the objective, mechanical rhythm of social facts, which replace at every moment the personal time, the 'lived time,' that Charley, Margo, and Mary French are incapable of possessing. It is social time, external time, that will carry them along in its inexorable unfolding" (130). While this essay intends to look beyond the mere "social" time and closer to what Magney describes as "external" time, I also which to argue that the external time that Magney gets at here is a time or rhythm set by capitalism itself.

No conception of thinking historically via narrative would be fulfilling without utilizing the theories of Hayden White. Here, I wish to utilize his theories in order to demonstrate the strength of the historical narrative. I do so in order to explain why Dos Passos, who utilized newspaper and/or newsreel headlines and clippings as a motif for sixty-eight sections across the trilogy (these sections themselves will be discussed later), would place them essentially side-byside with long sections of narration of fictional characters' lives. This contrasts with how Dos Passos could have instead simply focused on the history that journalism was producing. Let us start with a passage from "The Structure of Historical Narrative":

We might say, then, that a narrative is any literary form in which the voice of the narrator rises against a background of ignorance, incomprehension, or forgetfulness to direct our attention, purposefully, to a segment of experience organized in a particular way. In realistic narrative representation—as against mythic or legendary representations - the narrator is both present and absent: present as a means of 
communication, absent as a means of communication that is transparent and does not block access to the segment of experience whose organization it is his purpose to reveal to us. It is the presence of an identifiable narrative voice that permits us to credit such "realistic" representations as a history and a certain kind of novel as "objective" accounts. Because we can recognize the directive function of the narrative voice, we can take account of it as one way among others of organizing the data being represented. (119120)

It is necessary for me to quote at such length specifically because the narrative that Dos Passos created within his trilogy, with its three different types of sections, is deceptively simple, as the three interact with each other only occasionally plot-wise, but as a whole they interact in intentional ways to make the narrative more illuminating from both a prose and a historical standpoint. How the novels that make up the trilogy come together in order to create an illustrative fabric that is at once both a narrative and a historical document is by putting those two things up against the "history" that was being peddled by those in power and those with the means to produce history as a thing to be consumed. This contrast is seen by the jarring shift from the narrative sections to the "Newsreel" sections and the "Camera Eye" sections. It is Dos Passos' use of his characters as narrators that are "present as a means of communication," but also how Dos Passos writes their narrative voice that makes their experiences "transparent." For an explanation of this, we turn to Jean-Paul Sartre's essay, "John Dos Passos and 1919."

First, Sartre discusses the varying degrees of proximity that Dos Passos' narration is able to provide: "We live in time, we calculate in time. The novel, like life, unfolds in the present. The perfect tense exists on the surface only; it must be interpreted as a present with aesthetic distance ... Dos Passos' time is his own creation; it is neither fictional nor narrative. It is rather, 
if you like, historical time" (62). While I think Sartre's statement that time for the characters who have their own individual narratives is neither fictional nor narrative is a bit of hyperbole to make a point, his categorization of his narrative style as historical is what Dos Passos' was aiming for in the distance (per Sartre's "aesthetic distance") it lies from the characters, but has a closeness to the history that Dos Passos is providing.

Second, Sartre compares Dos Passos' narration to memory: "In Dos Passos, the things that happen are named first, and then the dice are cast, as they are in our memories" and he continues, "Not for an instant does the order of causality betray itself in chronological order. There is no narrative, but rather the jerky unreeling of a rough and uneven memory ..." (63). Examining how Sartre analyzes Dos Passos' narration, the narration not only falls under White's description of how a narrative is historical, but explicitly does so. Dos Passos' narration is both absent as far as considering the action that is occurring and meditating on it, but seemingly as present as possible with respect to the details of the lives of his fictional characters and the real history they occupy. As White describes it: Dos Passos provides a narration that is "transparent and does not block access to the segment of experience" and does so by essentially speaking of the experiences of the characters as if they were memories: sometimes focused on minute details, other times weeks go by in a sentence.

We will come back to further unpack Sartre's analysis later in the context of portions of the trilogy. I wish to return to the beginning of the longer White quote and complete our framing of the trilogy in a historical narrative sense. We must establish that the narration rises against ignorance, incomprehension, or forgetfulness. The last especially is in play with theorizing of Dos Passos' narration as memory. As White explained in The Content of the Form 15 years after "The Structure of Historical Narrative": "In this respect, that manner of being-in-the-world that 
we call 'historical' is paradoxical and cannot be apprehended by human thought except in the form of an enigma" (181). This summarizes our analysis of Dos Passos' near and yet far narration of his fictional characters' histories, itself an enigma that recites the past as if it is present. However, White continues his theorization further: "[The truth of narrative histories] resides not only in their fidelity to the facts of given individual or collective lives but also, and most importantly, in their faithfulness to that vision of human life informing the poetic genre of tragedy" (italics mine) (Content 181). What I hope is clear is that we have established Dos Passos' narratives as their own truth, as these are fictional characters, but their histories can only be understood as the truth of their individual, sometimes collective (as characters come together at points) lives and that these histories are representative of the reality of the period that USA "fictionalizes" and they inform the incoming tragedy that is The Great Depression. But they also inform a much greater tragedy, that is the loss of time and history at the hands of capitalism and consumption.

The United States of this period was one that had their collective belief in manifest destiny come to fruition. As we know, capitalism relies on constant growth and expansion to sustain itself. By 1910, when the trilogy begins, the natural resources within the territory of the continental United States were documented and already being exploited based upon the demand of individuals and corporations at the time. However, corporations were watching as unions began to gain power and support with coal strikes in the early 1900s and the IWW being founded in 1905. Capitalism naturally wants to continue its expansion and end the organization of workers. They could do this by controlling time and history within the minds of the citizens, discourse, and text. 
Dos Passos meditates on how Capitalism controlled and changed time and history in the minds of US citizens in his Camera Eye sections and how this plan was carried out with his Newsreel sections. The Camera Eye narratives exist as what is seen through the eyes of a nameless person or persons but reproduced and seen instead through the lens of the camera, a product made for reproducing images. What is lost in these sections is some of the humanity of the events and they are now relayed in a stream of consciousness that is difficult to piece together. Then even further into the realm of the reified, the Newsreel sections are completely produced by machines. While humans are involved with producing the text of these headlines, they are ultimately subject to capitalism as a machine by needing to tell the country what it wants to hear in order to sell. In addition, a newsreel functions as an even faster version of "The Camera Eye," flashing images at 24 frames-per-second, giving the human eye competition for the viewing of images of the world while at the same time, the newsreel is projecting its own version of the world, one in which the human eye is at the mercy of the newsreel for a picture of what is happening in the world. Turning to Richard Terdiman, he states that "As the title of a recent study of the period by David Lowenthal puts it, beginning in the nineteenth century the past began to look like a foreign country" and continues by stating that "The 'long nineteenth century' became a present whose self-conception was framed by a disciplined obsession with the past" (5). We can then theoretically conceive of an opportunity in which for corporations to insert their own agency into the conception of time and history that were created every single day.

The opportunity for this lays in the stream of consciousness chaos of the Camera Eye sections. These autobiographical sections from Dos Passos' own mind express as closely as possible how the human idea of memory works and its lack of ability to express itself clearly and 
remember anything more than particular details before getting lost in something completely different. There is absolutely no order to them. Terdiman agrees with this assessment of memory: “... [memory] is an essential postulate in our attempt to explain how the world remains minimally coherent, how existence doesn't simply fly apart” (9). This in itself would drive Frederick Winslow Taylor crazy. Taylor is one of the few biographies within the trilogy in which he's actually referred to by his full, given name; his name is even the first three words of his section, titled "The American Plan." Contrasting these biographical sections with the Camera Eye sections, Dos Passos establishes that he is able to write about the past of others than he is about himself, as the information on these others is documented, organized, and set to text, where his own life can only be recalled through the faultiness of memory.

However, calling the sections "Camera Eye" seems like a misnomer, considering it is a human's recollection of his own life during the period in which that particular part of the narrative is taking place. What I find here is that the incredible incoherence of these sections is an attempt to model human memory, something that was being commodified at the speed of the production and reproduction of devices that were created to model the past, the camera itself. The box camera was widely available in the beginning of the $20^{\text {th }}$ century, the technology had become readily available and people would be able to take their own photographs to remember the past. Even though photographs would be taken by someone who had bought a camera and film, unless they had access to their own dark room, there was no way to develop the photograph. This created a labor process of production that in essence attempted to replace the process of memory and recall. Humans trusted these machines and these processes of labor to both imprint the memory, store it, and by looking at the photograph, recall the image better than the human mind was capable of. This is why the name of these sections, "Camera Eye" is a 
combination of both the human and the machine, this is the human attempting to replicate its own replication of the process of memory, and in the process, reifying memory, time and history, as photographs served to replace the human need for memory and recall, but would be subject to a labor process that the user of the camera and the developer actively participated in.

In addition to the memory of the eyes being replaced, information recall was attempting to be replaced by newspaper headlines and clippings, hence the existence of the "Newsreel" sections. This in itself was another attempt at replicating a human process by combining the labor of humans with machines. Lying between the "Camera Eye" sections and the narrative sections, the "Newsreel" sections offer actual newspaper headlines and clippings. These were delivered to people daily and reported on things from the day before, in essence writing peoples' memories for them. These sections tell the story of how these newspapers created a confidence in corporations and journalism. If we examine examples from the novels, they get more and more focused on reporting the successes of businesses and the market as the trilogy goes on. The $42^{\text {nd }}$ Parallel discusses mostly things expressing anxiety about the future and reports on the US's place in the world and the final "Newsreel" section of the novel begins with "U. S. AT WAR" (367). Nineteen Nineteen's "Newsreel” sections report on the happenings at home and abroad concerning World War I, and finally The Big Money's first "Newsreel” ends with "Charles M. Schwab, who has returned from Europe was a luncheon guest at the White House. He stated that this country was prosperous but not so prosperous as it should be, because there were so many disturbing investigations on foot" (36). By the end of the novel, the second-to-last "Newsreel" (at which point we are approaching the Great Depression) features headlines such as "BROKERS LOANS HIT NEW HIGH" and "MARKETS OPTIMISTIC" (471). The progression of the "Newsreel" sections tell their own story, the story that capitalism wants people to subscribe to, 
considering in essence, capitalists who run the companies that produce the newsreels produced these headlines themselves, as newspapers themselves are commodities to be consumed after being produced.

To fully understand the impact of both the "Camera Eye" and "Newsreel" sections, we return to Terdiman and his analysis of how commodities and memory interact. Terdiman explains:

... the connection I have suggested between memory and the commodity reminds us that one of the most powerful reflections on the problematic character of reality in the capitalist period itself turns squarely on memory. . . . Lukács's celebrated "Reification" essay in History and Class Consciousness . . . theorized the reflexes in consciousness and in culture of the domination of the socioeconomy by commodities. (14)

And he continues: "Essentially, 'reification' is a memory disturbance: the enigma of the commodity is a memory disorder. . . commodity fetishism can be seen as pertinent—indeed a quintessential — example of just the opacity in mnemonic functioning that was coming to consciousness in the post-Revolutionary period" (italics his) (14). To summarize these quotations, Terdiman is stating that reality in the capitalist period was set by the memories of the people who participated in the economy. Because the economy was based on the commodity fetish and the reification leads people to forget the labor and interests that are tied to the commodity, that is why Terdiman considers the commodity itself to be a memory disorder, it causes participants in the exchange of commodities to separate the object consumed entirely from the humans and the labor that produced it; or, as Terdiman states: "The experience of commodification and the process of reification cut entities off from their own history. They veil 
the memory of their production from their consumers, as from the very people who produced them" (14).

From the entirety of this discussion, we can see both of these forms, the photograph and the newsreel as being commodities that are consumed widely. This is especially true in a time of economic boom, as more people could afford to purchase the box camera, film, and labor to develop photos, as well as to see movies where newsreels were played and purchase newspapers. Terdiman describes why these histories were taken up so readily by those who consumed them: “... the recollection of the past — particularly by that growing segment of the urban population who had grown up far from the cities where they had come to live as adults—obliged people to reconstruct the prehistory of their new environment in the effort to naturalize it" (6). There was a demand for a history of what the nation was and an idea of what the nation was to become. These reifications of time are what provided the people of the United States with the history and the future they were looking for at the same time. The issue was always in the production of these histories and the idea of the future. People were not conscious of who was producing these histories and ideas of a future, they just went ahead and took what photographs, newsreels, and newspapers informed them because they knew their memories to be faulty and incomplete.

This is why Dos Passos wrote the "Newsreel" and "Camera Eye" sections alongside these narrative sections. White tells us the power of narrative to construct history, which is only made more powerful by the fact that these narratives were constructed in such close proximity temporally and with the idea of an improved memory, one that can remember the plight of the age, but with aesthetic distance that provides us with the idea that these are the memories and stories of these fictitious characters. The issue at hand here, was that the rampant consumerism of the age alongside what Terdiman calls the "memory crisis" makes for an age in which 
capitalism and government together (recall Schwab's meeting at the White House) utilized a public looking for the past and future of both their country and their individual lives in order to establish a history and a future that would be to their benefit. That is why J. W. Moorehouse is the central example of wealth and power of all the fictional narratives within the trilogy, because he is a public relations man: he tells a public that is craving memories and a future what those things are and what they should believe. Dos Passos in writing his trilogy was not only attempting to model what he saw as being the actual history of the time but attempt to show that the reification of time and history via photography, newsreels, and newspapers was nothing more than supply meeting demand. His narrative sections feature characters that represent various aspects of the history that he witnessed and knew about. These characters of his invention are attempting to make their own ways in the world and either write their own history or escape out from under the thumb of the history that they realize is coming. In the early nineteenth century, manifest destiny supposedly ended, and capitalism and the United States were looking for their new frontier. Terdiman and Dos Passos both were able to diagnose the new frontier as being temporally situated. Thus, capitalism has continued to dominate the production of history as far as how this country thinks of itself. That's why the narrative had to end with the Great Depression, it is a time in world history that is named for the economic situation of the time. Even the negative components of capitalism have come to become the namesake for one of the darkest periods in this country's history.

Speaking of J. W. Moorehouse, we can see his character arc as an illustration of how time can change on the individual level according to the wealth one has. We also see a frightening dismissal of the power of journalism in favor of advertising for controlling the reification of history. During the start of Moorehouse's life, he is not well off. Dos Passos even refers to his 
appropriate job at The Times Dispatch as "a bad time for Ward" (260). However, on "[o]ne day in the Spring" when Moorehouse goes to interview a travel lecturer, everything changes for him when he runs into Mr. McGill and their conversation both lends itself to the control of time and the idea that the history of the US is something that can be altered by those in power, that history and therefore time is at the mercy of those with power:

"Why, hello, Moorehouse," said Mr. McGill, in a casual tone as if he'd been seeing him all along, "I'm glad I ran into you. Those fools at the office mislaid your address. Have you a minute to spare?"

"Yes, indeed, Mr. McGill," said Ward. "I have an appointment to see a man but he can wait."

"Never make a man wait if you have an appointment with him," said Mr. McGill.

"Well, this isn't a business appointment," said Ward, looking up into Mr. McGill's face with his boyish blue-eyed smile. "He won't mind waiting a minute." ... Mr. McGill explained ... he was looking for an ambitious and energetic man to handle the advertising and promotion [of the Bessemer Metallic Furnishings and Products Company].

"I remember that booklet you showed me in Paris, Moorehouse, and I think you're the man."

Ward looked at the floor. "Of course that would mean giving up my present work."

"What's that?"

"Newspaper work."

"Oh, drop that; there's no future in that ..." (263) 
There's the ability to ignore appointments, asking if Moorehouse has a minute to spare and Moorehouse stating that he would have to give up his present work and that there's no future in newspaper work that establishes the sort of ability to bend time that Moorehouse and McGill possess.

Dos Passos highlights this power by providing us a character named Oliver Taylor, who is Moorehouse's officemate and eventually his friend. Picking the last name of Taylor already gives us the idea of connecting him with Frederick Winslow Taylor, but Dos Passos really drives it home by including the detail that "Oliver Taylor was a firstrate tennis player" (263), as Frederick Taylor was as well. We do know that they are not quite the same person, as the aforementioned biography section featuring Frederick Winslow Taylor exists, but the connection to the power of the early $20^{\text {th }}$ century is there and Moorehouse is swept into it.

Appropriately, there is not much that Dos Passos puts between Moorehouse's last two sections of the whole trilogy, as I argue that his power allows himself to remove himself from being written about or having a physical manifestation of his recorded history (fact or fiction) exist. However, the biographical section entitled "The Prince of Peace," about Andrew Carnegie is written between them. A fitting part of that section continues Dos Passos' detail of what the developments of capitalism in the early $20^{\text {th }}$ century were really about:

he had confidence in railroads, he had confidence in communications, he had confidence in transportation, he believed in iron. (278)

As far as I am concerned, confidence is certainly different than a "belief in" something. All of these things that Carnegie had confidence in were timesaving mechanisms. Railroads could 
move people (read: labor) and goods faster than anything before them and communications systems such as the telephone allowed for messages to be delivered much faster.

This confidence matches what the general public was feeling. They still believed in journalism: the newspaper they got to read every day. However, they did not realize that people in the mold of Moorehouse were entrenching themselves within the journalism industry and made these objects that wrote what was then the present day and what would soon become history. It was at the turn of the century that advertisers began to create misinformation or run studies that are deliberately misleading and then would report on misleading studies done by corporations in order to sell more product.

For contrast, Richard "Dick” Ellsworth Savage spends much of one of his sections in Rome, examining what's left of their history:

... they hired a cab with their last ten lire to take them out to see the Colosseum by moonlight. The great masses of ruins, the engraved stones, the names, the stately Roman names ... the great masses of masonry full of arches and columns piled up everywhere into the night, the boom of the word Rome dying away in pompous chords into the past, sent them to bed with their heads whirling, Rome throbbing in their ears so that they could not sleep. (207)

This is a stellar image of what advertising's goal is: creating stately names of products, writing jingles, phrases, and songs that create their own history, a history that stands the test of time like the Colosseum. Now, however, we can see that in the heads of these powerful figures, the idea of Rome is "dying away in pompous chords into the past," as the history they are creating will replace these mere images of Rome and a great civilization. Civilizations will no longer be measured by architecture or art, but by how they are able to create an image for themselves. 
Thus, the power of PR and headlines is the power to write an idea like Rome's Colosseum into a person's memory. If someone constantly reads about how the economy is what drives the United States forward and makes their country, and by proximity, themselves, powerful, then that is what they will believe: that above all else, the United States economy must be maintained.

One of the strongest examples of public relations and advertising writing history and mythos to come out of the period is the idea that breakfast is "the most important meal of the day." This idea is exemplary of this merging of advertising and "journalism" and the work of Edward Bernays is something that needs to be understood in how it has altered the history of the United States and the memory of its populations. Bernays worked in advertising and assisting both powerful political leaders such as Calvin Coolidge and Herbert Hoover, but also worked for some of the most powerful companies to ever exist: United Fruit Company, General Electric, CBS, and others.

We can look to his own book, Propaganda, released in 1928, but is very much a culmination of his work before, during, and after World War I, and understand that advertisers or "PR Men" like Moorehouse knew what sort of power they held. The book starts off with the following: "The conscious and intelligent manipulation of the organized habits of the masses is an important element in a democratic society. Those who manipulate this unseen mechanism of society constitute an invisible government which is the true ruling power of our country" (9). In this quote we can see in the phrase "invisible government" that there exist two separate histories. There is a surface history that we are told upfront via journalism, but below the surface there exists a "true" history that elaborates on all the various connections and powers that are actually at the center of creating this history. This false surface history is the object that we examine every day, whether through the newspaper, internet, or television. 
Now that we have discussed how capitalism manipulates our idea of history, the past, and how we conceptualize "the times," we need to understand another manipulation that lay under the surface. The eight-hour workday is something that many accept as simply a part of American culture and serves as a contribution that capitalism gave the people. Unfortunately, that is not even remotely the case: time exists as something of which we each have a limited amount. Capitalism exploits those under it as an "invisible government" or an "invisible organizer" of our own individual time. This is another under-the-surface phenomenon we will have to discuss in our next chapter. 


\section{CHAPTER II: LABORING UNDER TIME}

Thomas Pynchon is an author who has spent his entire career historicizing and attempting to make sense of space and time. However, his lengthiest and one of his more recent novels, Against the Day, has proven to be a different beast in both its breadth and depth. As Heinz Ickstadt wrote in comparing Against the Day to Pynchon's other novels: “. . . Against the Day seems even more decentered, even more incoherent than the previous novels ... its narrative space organized as a multidimensional space-time continuum” (Ickstadt 224).

Whilst the novel is generally chronological and deals with many events that can be confirmed to have occurred, like the Tunguska Event and the Ludlow Massacre, this both gives us signposts to tell us when and where we are, but also lulls us into a false sense of historical security. Pynchon's always thorough research is on display yet again, but even without the haze of paranoia looming over this novel like so many others, there are always details that make us question our own sense of history, not only what we believe to be the generally held conception of history at the time, but Pynchon's conception of history as well. Again, this isn't something new to Pynchon novels. For example, $V$., his first novel dwells on the fact that Herbert Stencil himself is taking us through these visions of history along with all of his biases and things he wants to see in these histories, which distort them despite the fact that he is looking for some truth about $V$. in these histories. However, just like with narrative, Pynchon's conception of history and his issues with the idea of a "conception of history" are taken to anarchical extremes in Against the Day. Pynchon even establishes history as a potential "liberator" of anarchists and socialists, that is, "if they could somehow survive to see the day" (654).

The anarchic nature of time is demonstrated three-fold in Against the Day. First, is the idea that time travel is possible. With the publication of H. G. Wells' The Time Machine in 1895, 
people were inspired to attempt to make a device that could allow one to travel backwards and forwards in time. Pynchon spends a few sections of the novel deriding such a concept, starting with the Chums of Chance supposedly taking a trip to the future in a time machine created by Dr. Zoot. Their trip takes them to a time where "Everywhere rose the smell of excrement and dead tissue" but when the Chums return and Chick Counterfly asks what they saw, Dr. Zoot tells them "'It's different for everybody ...'" (404). Then, later, the Chums and Professor Vanderjuice come across a whole junkyard full of failed attempts at time machines that Pynchon describes as "... A strewn field of conjecture, superstition, blind faith, and bad engineering ..." (first ellipses Pynchon's) (409). These failed attempts demonstrated the inherent anarchy of time, that it resists any sort of device or system that would allow one to travel through it. In addition, we might see time and reality itself pushing back against human attempts to bring time under human control, as Padzhitnoff states about the Tunguska event: "'It certainly resembles a capacitance effect, though on a planetary scale - a slow, incremental investment of energy, followed by a sudden catastrophic payback" (781-782). And this demonstrates that time itself will resist any sort of attempt to control it, as Pynchon postulates that could be a potential reason for the occurrence of the Tunguska event. Richard B. Saltman in his reading of Michael Bakunin states: ". . a any given historical stage, man's scientific knowledge was always incomplete and inadequate" (Saltman 75). And the case is no different here. Hence, the novel itself moves away from a scientific conception of controlling or manipulating time to one that falls more under a capitalist conception of time, which is what, as I will discuss further, pushes against the anarchy inherent to time itself and to the time that people have unto themselves and puts it under the control of the ruling classes. 
Secondly, with Against the Day, Pynchon was attempting to give a history of fictional characters that spans almost 30 years. To even attempt such a thing speaks to the realm of impossibility, but that is what I believe Pynchon went for here and he is fully conscious of that. Throughout the course of the novel, there are gaps in these characters' histories. They either change location and we don't know how, or something happens to them and we are not told the full story in order to demonstrate the futility of creating a full history of any period. Pynchon writes this digression into the novel as well: ". . the tranquil Old Man with syrup-slow ease continuing his digression, fading through the afternoon, into obsessively detailed allegations of odd latrine behavior ... each set of images chaining away for uncounted leagues, everything reflected, headed for the Point at Infinity along a great slow curve...." (last ellipses Pynchon's) (422). Here, Pynchon is demonstrating that even to tell the full history of someone using the bathroom would take an infinite amount of time: the detail necessary to fill in every gap in the history would take an infinite amount of detail to fill. Hence, why he ends by saying the digression reaches infinity and then appropriately ends the paragraph with ellipses. This scene connects back to the Chums' experience in the time machine in that the details and what people see in the same event, the same occurrence will always differ and they will relay those details and fill in those gaps differently every time. In addition, this problematizes the concept of time travel and its usefulness. For example, if one wanted to change the future, a point "B" in time, and they live at a point "A" in time, there are simply an infinite amount of things and details occurring and existing between those two points both in the material and non-material worlds that being able to have that level of control to make the future look like what one wants it to at point "B" is an impossibility. 
And finally, the third way that Pynchon considers time is the attempt by businesses to control the time of individual peoples via setting work hours. This is one of the main components of the dark vs. light theme in the novel, as whenever and wherever there is light, labor can be extracted from a worker since they can see their work. With the advent of electricity and the lightbulb after the 1893 Chicago World's Fair, it became possible to light spaces efficiently and cheaply for businesses, leading them to demand longer hours of their laborers. The Chums of Chance note this:

While crossing the Continent the boys had expressed wonder at how much more infected with light the night-time terrains passing below them had become-more than anyone could ever remember, as isolated lanterns and skeins of gas-light had given way to electric street-lighting, as if advanced parties of the working-day were progressively invading and settling the unarmed hinterlands of night. (1032)

This equates the robber-barons with the imperial colonizers of the American continent, but instead of merely colonizing space, they are colonizing time. It is from this conception that I believe Pynchon derived the title of this novel, as anarchists are fighting against the day's colonization of night via big businesses controlling light and creating a world in which rest (something that typically takes place at night) is a foreign concept for all but the ultra-wealthy. And this colonization of the day is also what accelerates the spread of the idea of anarchism, a rebellion against the hierarchy attempting to control day and night, and by that measure, time itself.

If we look at Georg Lukács' definition of reification, we can begin to understand how time is reified during the labor process, independent of the reification of the laborer: "What is of central importance here is that because of [the situation in which products of labor become 
commodities] a man's own activity, his own labour becomes something objective and independent of him, something that controls him by virtue of an autonomy alien to man" (86-87). The setting of a "workday" in itself lends itself to the fact that time is independent of man. This coining of a general conception of time devoted to work, much like how Lukács summarizes the reification of labor: "Thus the universality of the commodity form is responsible both objectively and subjectively for the abstraction of the human labour incorporated in commodities" (87). While the idea is that the laborer is free to sell his labor on the free market and only accept jobs whose time works best for the laborer, as we know, that is not the case, as the demand for jobs always outweighs the supply, meaning that the laborer must compromise their needs, and this means that they must cede their control of their own time and give it to whomever can provide them with wages. It is this "universality" that labor and time both share in how they are treated in the labor process that leads us to understand that labor is not the only thing that's reified in the process, but time is as well.

We can also take a closer look at Lukács' understanding of how time is invested into the labor process to further conceptualize this reification. We have looked at how he defines the reification, but we must now quote and analyze his conception of the labor process:

On the one hand, the process of labour is progressively broken down into abstract, rational, specialised operations so that the worker loses contact with the finished product and his work is reduced to the mechanical repetition of a specialised set of actions. On the other hand, the period of time necessary for work to be accomplished (which forms the basis for rational calculation) is converted, as mechanisation and rationalisation are intensified, from a merely empirical average figure to an objectively calculable work-stint that confronts the worker as a fixed and established reality. (88) 
While Lukács helps us to understand the objectification of the laborer as person, that "his personality, its [metamorphizing] into a thing, an object that [the laborer] sells on the market" he also contends that time is also separated into its own thing, its own object separate from the laborer, but only after the laborer has sold his labor on the market. While the quote above details a "work-stint" that is objective from the view of those with the power to purchase labor on the market, the time within that work stint is much more difficult to "fix and establish" than the laborer's physical being.

We can return to Pynchon to further understand this. If we think about the impossibility of scientifically reconstructing time, that there are an infinite number of intervals of time between point " $\mathrm{A}$ " in time and point " $\mathrm{B}$ " later in time, then we can see the anarchy inherent within time (or "entropy", if we wish to use the term sometimes more associated with Pynchon). This between the distinct themes of doubling and anarchy within Against the Day, we get this scene between Reef and Yashmeen:

... she put her faith, like a good Emotional Anarchist, in the Law of Deterministic Insufficiency.

"What's that?" said Reef.

"Like a card comes up that you could never have predicted."

"Oh but hell darlin, if you've been counting 'em careful enough-—"

"That may be true for only fifty-two cards. But when the deck is orders of magnitude larger, perhaps approaching infinity, other possibilities begin to emerge. ..." (last ellipses Pynchon's) (862)

Reef here provides us the view of the capitalist whose venture into science in order to attempt to control time directly via time travel. That if one is meticulous enough, that one can control all 
aspects of a thing if you "[count] 'em careful enough," and Yashmeen informs us that when one only has a limited number of possibilities to account for, such as only 52 cards in a deck of normal playing cards, it certainly is possible. So the laborer as physical being, being one system in itself, is simple to account for. However, when we have to conceive of the entirety of the labor process, an infinite number of things to account for begin to crop up.

Even within extremely simplified means of labor, Ford's assembly line and Taylor's appropriately named "scientific management" (because, at least in Pynchon's novel, it is a movement of scientific control from an attempt to control time itself in a purely scientific venture to one with business and economic applications) and how dehumanizing they were, it is impossible to completely control every part of the labor process and the time that it takes to perform even the most simple of steps. To explain further: if we see time as inherently anarchical, capitalism and imperialism's movement to stamp out anarchy is an extension of their attempt to control not only every portion of the labor process, but each second (and units of time getting infinitely smaller) of the laborer's workday.

We can demonstrate the importance of time as far as producing the commodity and surplus-value by examining the writings of Frederick Winslow Taylor and Thorstein Veblen. As Martha Banta tells us “[Veblen] singled out three consequences of 'maladjustment' in the industrial plant (itself a word suggestive of living, growing things subject to decay), couched in terms familiar to any moralist: idleness, waste, and hardship" (my emphasis) (92). Veblen specifically lists idleness, or, a period of time in which "work" is not being performed exists. Contemporary workplaces have even equated such periods as closer to "waste," which Veblen also discussed and some even call it time "theft," which places it in the realm of criminal activity. And looking at Taylor's The Principles of Scientific Management, he states that "the 
most important object of both the workmen and the management should be the training and development of each individual in the establishment, so that he can do (at his fastest pace and with the maximum of efficiency) the highest class of work for which his natural abilities fit him" (emphasis mine) (12). Although Taylor, like Veblen, was also conscious of the laborer attempting to be idle and do less than the maximum possible: "doing away with slow working and 'soldiering' [(deliberately working slowly so as to not do a full day's work)] in all its forms and so arranging the relations between employer and [employee] that each workman will work to his very best advantage and at his best speed ... would result on the average in nearly doubling the output of each man and each machine" (emphasis mine) (14). And speed, simply put, is a factor of time.

Returning to Lukács' discussion of the labor process, we can see that there is an understanding of the separation of time and the worker from what he is producing, however, there is a lack of attention given to the time, whereas most of his essay focuses on the human consciousness and physical being. Lukács merely uses time as a step to help demonstrate the reification of the laborer:

Thus time sheds its qualitative, variable, flowing nature; it freezes into an exactly delimited, quantifiable continuum filled with quantifiable 'things' (the reified, mechanically objectified 'performance' of the worker, wholly separated from his total human personality): in short, it becomes space. In this environment where time is transformed into abstract, exactly measurable, physical space, an environment at once the cause and effect of the scientifically and mechanically fragmented and specialised production of the object of labour, the subjects of labour must likewise be rationally fragmented. (90) 
While Pynchon connects space and time together in his novel just like Lukács uses Marx to connect them in commodity production, I think Lukács is oversimplifying time in the labor process. It neglects the fact that Taylor did his time studies wherein he measured the time it took to do a task and arranged the assembly line according to those times as well as the time-motion studies done by Frank and Lillian Gilbreth, which were actually done in contrast to Taylor's studies. These time-motion studies were more objectifying because they simplified the movement of the laborer and made them simpler and more machine-like. Of course, reification is not the inherent intention of these changes to the standardization of movement of the laborer so much as it was reducing the amount of time that needed to be put into that step of the labor process in order to complete it, allowing the laborer to produce more in the same amount of time.

A reminder that the attempts to create time machines that Pynchon writes about were preliminary movements to essentially conquer time itself and make it subservient to capitalism's whims. However, the fact that time could not be expanded or manipulated directly meant that capitalism needed to find a way to collect time as a resource. Ultimately, this was another way in which capitalism found a way to exploit its workers. What I mean by that is that time is a limited resource in any capacity in a non-indefinite scale. For instance, time as a concept, is infinite. However, on the level of the corporation, the manager, the laborer, and even, as Marx argued, on the level of capitalism itself, time is limited. These things will cease to exist at some point, so when one of these people or concepts devotes time to something, they are, in essence, giving up a limited resource to do so. The issue between the parties mentioned previously is how each party's time is valued.

For example, the laborer is often expected, as Taylor wanted it, to be productive at all times and to use their time productively. The common laborer even carries this idea with them 
outside of the workplace considering that in Western culture, actions that are not seen as "productive" are not worthwhile and considered a "waste of time." In contrast, the manager whose job it is to supervise and essentially set the "best process" for laborers, that is, the most time-efficient way of doing things, is not judge on their own use of time, but how the time of those under them is used. Understanding time as a natural resource, as something that is created independent of human control, that is, time is not human-made but can be manipulated by humans like other natural resources can help us understand the power of capitalism's control over time, just like how companies like Nestle essentially steal and bottle water in front of former colonies in Africa that are starving for water and sell it to them.

To connect my last two points explicitly, capitalism assigns value to the time of various people within its own hierarchy. So when we talk about the labor process becoming a collection of smaller and smaller actions as a result of the specialization of labor, we can also see running parallel a specialization of temporality. Employee A should spend X seconds doing this job for Y hours of their day and employee B should spend $\mathrm{Z}$ seconds doing another job for $\mathrm{N}$ hours of their day and so on. Of course, of the parties that we mentioned earlier, it is the common laborer that has their own time specialized and scheduled. Even breaks from the production line are scheduled according to people who specialize in that sort of thinking and planning in order to allow for maximum productivity. In contrast, parties higher up in the hierarchy essentially set their own schedules and do not answer to anyone as far as how exactly they are utilizing their time. Their effectiveness is measured by how well they ensure that those under their supervision are utilizing their time efficiently.

Of course, even with "scientific management" and all of this supervision and control exercised on how employees spend every millisecond (or less) of their time, complete control 
over time cannot be fully realized. Even with "best practices," the sheer unpredictability of what happens in a modicum of time cannot always be planned for or fully controlled. Even if a laborer moves a lever a particular way one-thousand times in a particular day utilizing the same "best practice" to do so, there will be variabilities in many of those occurrences in time. The laborer may stop to scratch an itch, he may experience fatigue and pull the lever more slowly as the day wears on, and the milliseconds of difference, because they are so small, cannot be fully calculated at all times. This gives time an inherent anarchical quality that Pynchon realizes within Against the Day and he utilizes the novel to elaborate on the attempts of early $20^{\text {th }}$ century capitalism and imperialism to throttle the inherent anarchy of temporality.

And this is why Pynchon is so focused on anarchy in his novel Against the Day. It is anarchy itself, included in that, the anarchy of time that are fighting against both the concept of the endless working day and the day itself being the only time at which capitalism can run at full efficiency. Just like I explained time to have no limit to the ways it can be divided up, Pynchon utilizes this in his "doubling" concept within the novel. While the idea of doubling that Pynchon explores in combination with many of the themes and all across the novel seems to be representative that there are only two possibilities, I think limiting that conception to two possibilities would be incorrect. While Iceland spar is a material that is sought after in parts of the novel for its double refraction, examining the cover of the US hardcover edition (which features "AGAINST THE DAY" and "THOMAS PYNCHON" refracted in several directions, with several different typefaces, onto a piece of paper), we see way more than just two instances of the novel's title and Thomas Pynchon, which I find to be the cover implying that there are many layers, or levels, to this doubling effect. Hunter Penhallow explains this layering concept to Lew Basnight: 
"Someone is clearly fascinated" . . "with Crouchmas's simultaneous attachments to England and Germany. As if just having discovered a level of 'reality' at which nations, like money in the bank, are merged and indistinguishable - the obvious example here being the immense population of the dead, military and civilian, due to the Great War everyone expects imminently to sweep over us." (903)

This concept of levels of reality means that the doubling can occur at each layer. Who's to say how many layers exist? This means that the doubling itself is infinite, meaning infinite possibilities. This concept of infinite possibilities is expanded on in the earlier quoted conversation between Yashmeen and Reef.

While Yashmeen offers a further explanation of the "Law of Deterministic Insufficiency," which is not an actual law that exists within the realms of science, I would explain it as there being infinite possibilities at any given moment for a person to make choices. Even if said choices were binary or doubled, the fact that there are so many decisions one can make throughout each day even, the possibilities truly are endless. This is the other reason for the occurrence of World War I, to attempt to put a limit on the possibilities of people. That is what Penhallow means when he says "everyone expects imminently to sweep over us". Pynchon also notes this in other places in the novel, as Ratty explains to Yashmeen about the reasons for war: "Anarchists would be the biggest losers ... . every small victory Anarchism has struggled to win so far would simply turn to dust. . . Anarchism now is the idea that has seized hearts everywhere .... A general European war ... would be just the ticket to wipe Anarchism off the political map" (938). In addition, Reef, Yashmeen, and Ljubica experience this directly when they find themselves in the midst of the Second Balkan War: "Each day then would show Reef, Yash, and Ljubica only a further narrowing of choices, as they were pressed by the movements of forces 
toward the west and south" (963). With this war, we see a narrowing of choices, however, this does not mean that the possibilities are not infinite, just slightly lower than infinite. Mathematically, if a number is approaching infinity, and one puts a limit on it, it is still approaching infinity. Anarchy is present in all of the characters and within all of us via this concept of doubling, driven to its anarchist extreme. War can put limits on infinity, but infinity is still there.

While I have demonstrated how Lukács oversimplified the connections between time and space in how he examines the labor process and how it reifies, the use of World War I by national governments to restrict anarchy and solidify spaces in Against the Day is something that needs to be examined in determining just how imperialism connects with the reification of time. Even though much of the world is already settled during the setting of the novel, space, and by connection, time, is still something that resists control, and Pynchon demonstrates this through the concept of mapping. Pynchon, having already explored the troubles of mapping thoroughly in Mason \& Dixon, returns to it in Against the Day, his very next novel. The difference here is that anarchy, which we have also connected to the concept of time, comes into play at this point in history. Benton, who has explored anarchy in most of Pynchon's novels, concurs, stating about Mason \& Dixon that "Pynchon remains committed to many of the social and political concerns that mark his previous novels . . but a treatment of anarchism itself is conspicuously absent" (Benton 193). So Pynchon made sure to make the two concepts, anarchy and space, two concepts we have connected with time as a resource, clearly aligned in Against the Day.

We can already see this anarchy within mapping developed by looking back at the discussion of Pynchon's attempt at detailing the lives of characters, but reiterating that impossibility of knowing or documenting all of the details here. Piekarski, Kevorkian, and 
McKetta elaborate: "Against the Day attends to the powers and perils of mapping, not just by describing maps throughout the text but by invoking mapping as a metaphor for charting the trajectories of individuals, for determining their narrative fates" (Piekarski et al. 48). And they go on to state that "as a thematics within the novel, one name for a resistant disregard for mapping is anarchy" (authors' italics) (Piekarski et al. 54). Just like time and the novel itself as physical things, space, both open space and the space and time characters choose to occupy, in this novel resists being fully known and being organized according to the whims of individuals, whether they are in power or not, and even by Pynchon himself.

However, the phenomenon exists more broadly than just within each individual character's tale as well. Various characters examine maps that display all sorts of different things and different geographies. For example, when Kit Traverse runs into Fleetwood Vibe near Siberia, shortly after the Tunguska event, Fleetwood "[brings] out a map, of sorts, mostly in pencil, smudged and beginning to be split at the creases, decorated with cooking grease and cigarette-burns" (789). This map was either drawn by someone else or is a result of Fleetwood's mapping of the area. If anyone else were to look at this map, they would likely not be able to fully understand it and we do not know if Fleetwood, who I assume is named so because he goes his own way (a reference to the song "Go Your Own Way" by Fleetwood Mac) relative to the rest of the Vibe family, can even comprehend the map fully. That said, he reveals to us the reason he's out here searching for places not on the map: "'I have since learned of other cities, out here, secret cities, secular counterparts to the Buddhist hidden lands, more indelibly contaminated by Time, deep in the taiga, only guessed at from indirect evidence ..." (790). Fleetwood is searching for places not on the maps, things that are merely implied to be there. Of course, these things "contaminated by Time" are places where time is not something that has 
been reified. Hence why people do not know whether or not they're there: if they were reified by imperialism and capitalism they would be visible, but because they have not been swept up in the process, they are able to remain invisible and the time that exists within these areas is allowed to remain free and belonging to the people of those spaces.

Similarly, the borders of nations, something very abstract and is merely implied to be there by bold lines on maps, were a huge point of contention during this period in world history. Even though Pynchon focuses little of the text on World War I itself, the war looms over the novel's chronology as some dark thing that history will soon experience. World War I was the war of trench warfare, and these trenches essentially served as new borders for each country, as trenches were dug or existing trenches taken by a different country's troops, borders, even though they weren't constantly being marked down on a map, were constantly shifting. Ultimately, after both World War I and one of the armed conflicts that Pynchon does focus on, the Second Balkan War (which itself and the First Balkan War were both fought over territorial disputes), were over, the Ottoman Empire and the Austro-Hungarian Empire were no more, and many national borders were redrawn and Germany's colonies given to the allied powers.

Despite this, Pynchon postulates that these physical borders no longer mattered by utilizing his dual characters Renfrew and Werfner. First he has Renfrew make his own reasons for the borders not really existing at all:

"Here then—keeping the North Pole in the middle, imagining for purposes of demonstration the area roundabout to be solid, some unknown element one can not only walk on but even run heavy machinery across—Arctic ice, frozen tundra—you can see that it all makes one great mass, doesn't it? Eurasia, Africa, America. With Inner Asia at its heart. Control Inner Asia, therefore, and you control the planet." (241-242) 
I think the mention of heavy machinery here is very curious, as at that point chronologically in the novel would be in the early 1900s, which is when J. P. Morgan created a marine shipping conglomerate known as the International Mercantile Marine Co. to attempt to monopolize the sea trade. I think this mentioning of the sea trade also plays well off of Werfner's conception of railroads:

"Werfner, damn him . . . is obsessed with railway lines, history emerges from geography of course, but for him the primary geography of the planet is the rails, obeying their own necessity, interconnections, places chosen and bypassed, centers and radiations therefrom, grades possible and impossible, how linked by canals, crossed by tunnels and bridges either in place or someday to be, capital made material — and flows of power as well, expressed for example, in massive troop movements, now and in the futurity ... each and every accommodation to the matrix of meaningful points, each taken as a coefficient in the planet's unwritten equation. ... (last ellipses Pynchon's) (242) Pynchon is saying here that despite all of this war supposedly over these borders (or possibly over railroad lines), the borders no longer matter. All countries are connected by technology that was booming at the time: 1915 had the first coast-to-coast telephone call in the United States, and in 1927, the first transatlantic phone call was made. So, as we can see, the physical space, interestingly enough found resistance to its organization through technologies that had come about in part due to capitalism, but at the same time, these lines on a map are supposedly the reason that World War I was fought, as these borders, themselves conceptual, resist organization. As it became easier to transfer people and products via steam power and easier to transmit information with the telephone (which is indeed, easier than having to use a telegraph), it essentially broke down the idea of organizing countries physically. If we look at the internet 
today, globalization of cultures has increased exponentially, leaving the idea of borders a mere geographical construct. So, in essence, capitalism in its development of technologies with which to transport people, products, as well as ideas, helped to unsettle the idea of borders separating people, economies, and cultures.

To further understand the power of the control of these spaces and to further connect space and time, we can look to how time was conceived by Native Americans before their own spaces and time were colonized by Europeans and eventually Europeans calling themselves Americans. Shepard Krech III's piece, "Bringing Linear Time Back In," establishes many of the ways in which Native peoples kept time and how the West overwrote Native time and historykeeping with their own. Interestingly enough, Natives had material ways of keeping time. Krech III tells us that Natives tracked time using "an impressive array of devices like knotted strings, notched and carved sticks, and pictographs on animal hides and other materials" (570-71). Of course, the Western capitalist conception of time is not purely material and is more about the production of a material. The colonization and forced relocation of the Natives in North America is well documented, but what can help us understand the reification and colonization of time is how Western ideas changed temporality within Native cultures.

Krech III also has very intriguing theories as to how the West even changed how Natives understood time and history. They state that:

Missionaries (and others) also introduced to native North America writing, texts, and literacy, which, like Western concepts of time objectify —in this case, speech. And as with time the analysis of their impact is polemical, in part because literacy is implicated in schemes of progress, development, civilization, and rationality inherent in the power structures of Western imperialism and colonialism. (emphasis mine) (575) 
What happened to the Native people of North America is not much different than what we discussed in the previous chapter with Dos Passos' USA trilogy. This objectification or reification of stories and the history that is created each day lends itself to manipulation and control. Krech III shares this attitude: "Writing makes it possible to fix events sequentially, to release them from an ever-changing present, and to enhance skepticism about the past. Thus, it holds the potential to transform oral historical narrative. Recording and chronicling the past does allow for greater precision and expansion in temporal calculations, but literacy often develops under restricted or controlled conditions. .."(575-76). What we can gather from this is that in creating a historical narrative that only goes forward, one that does not consider the past, capitalism and imperialism can attempt to create a history in which capitalism is the only way to live and that it has done no wrong. I also appreciate Krech III's diction in using the word "calculations" to make it clear that this is not any sort of accident. We see this today in Texas with a history curriculum that is attempting to eliminate knowledge of the atrocities of slavery. Time and history are no longer things unto themselves, they are mere productions of capitalism. History is only produced on a daily basis in written narratives because that is what the consumers within the capitalist structure demand.

The "new world" promised was the rewriting of a history that had already existed. Time and space existed before capitalism, but until the imperial spirit of the United States and capitalism as a system co-opted the space and time of the frontier, they carried no value insofar as their ability to be exploited. Even the time of those who settled across the frontier, taking the space of the native peoples did not have value until it was taken from themselves, reified, and put into the machine that is the process of commodity production. Long written are the dubious schemes in which capitalism has taken and expanded itself into spaces that didn't belong to it, 
but we need to continue to consider the ways in which capitalism separates time not only from those it takes space from, but from those who labor under it as well. 


\section{EPILOGUE}

While we began our study with post-Marxist conceptions from a more contemporary theorist, his arguments provoked us to defend Marxism from an atypical angle. While Laclau argues that one of Marxism's faults is that it lacks an objective perspective, part of what I argue is that time as a scientific concept is as "objective" (to use Laclau's terminology) a concept as we can look to in order to detail and elaborate on an antagonism between laborers and capitalists. This antagonism over time, from movements as small as those that were studied by time-motion studies, to the working day, to concepts such as overtime and vacation and sick days, time was established in the early $20^{\text {th }}$ century as the biggest antagonism between laborers and capitalists.

However, this antagonism has begun to fade in the United States and laborers are beginning to lose the fight over time. The United States is one of the few industrialized nations that still has a forty-hour work week, and in 2017 52\% of employed Americans had unused vacation time (only a limited amount of which rolls over to the next year) totaling 705 million

unused vacation days, an increase from 662 million days the year before. There is a guilt inherent in American working culture about "stealing" time from your employer, and this is what necessitates an examination of the struggle between laborers and capitalists over time.

As I established in the introduction, this struggle began when this culture of "national efficiency," as Theodore Roosevelt called it, was co-opted by industry and made into the attitude of the workplace. Capitalists and managers began stressing efficiency in everything their laborers did, at the cost of the humanity and the time of the laborer. These ideas spread even faster with the publication of Taylor's The Principles of Scientific Management.

Republicans at this time were also looking to continue American Imperialism and annex territories such as Hawaii and Puerto Rico. However, the national attitude was against continuing 
pushing the physical territory outwards, so the spirit of manifest destiny instead moved inward and instead of using space as its God-given right, it began to utilize time instead. It made laborers themselves into essentially colonized subjects of the capitalists, wherein time itself was the resource that was being robbed from these subjects.

By utilizing the texts of two different authors, John Dos Passos, who lived through this shift in American culture and American capitalism, and Thomas Pynchon, who published his novel on the early $20^{\text {th }}$ century in 2006 , we have two different authors whose reflections make two different declarations as to the changes precipitated by the capitalists' realization of their ability to manipulate time.

Dos Passos' USA trilogy and its different formations of narrative demonstrate the notion of capitalism rewriting history. While the narratives of individual fictional characters represent the vast majority of the text, their stories are lost in a sea of biographies of bigger names, newsreel headlines, and human consciousness combined with the production of the commodities in the "Camera Eye" sections. This leaves the only discernable histories as those determined by those who control the newsreels and those who can reach the public, those like Dos Passos' invented character, J.W. Moorehouse. The newsreels and biographies color human consciousness and create the "Camera Eye" sections, representative of the stream of ideas that go through the heads of consumers and how human thoughts now intersect with thoughts and ideas that are not their own and produce thoughts that are influenced by capitalists. This ultimately allows capitalists to write their own version of history as the perception of the public at any given moment essentially serves as the popular version of the history of that time.

Then, with Thomas Pynchon's Against the Day, he theorizes at failed attempts for scientists funded by capitalists to be able to time-travel and to manipulate time directly. And 
when those attempts fail, capitalists and others in power realize that they must expand by expanding the working day in the present. This is exemplified by Thomas Edison (a capitalist in his own right) and his "invention," the lightbulb, allowing for a 24-hour working day now that labor can reasonably be done at night. Pynchon also connects anarchy and time in rebellion against attempts to control the workday and establishes World War I as an attempt to solidify the borders of nations as well as quell the storms of anarchy and opposition to the endless workday. In establishing a historical point at which this manipulation of time becomes clearest allows further theorizing as far as how time has been manipulated by capitalists before and after this time period all the way up to the present day. It also serves to help establish scientific time as an "objective" site of antagonism between laborers and capitalists and assists in creating another way to examine the history of class struggle. While Laclau is correct that capitalism takes different forms in different geographical areas, leading to different threads of the history of class struggle, one thing that unites these histories is that capitalists have always attempted to manipulate the history of the class struggle and manipulate time itself. 


\section{WORKS CITED}

Banta, Martha. Taylored Lives: Narrative Productions in the Age of Taylor, Veblen, and Ford. University of Chicago Press, 1993.

Benton, Graham. "Daydreams and Dynamite: Anarchist Strategies of Resistance and Paths for Transformation in Against the Day." Pynchon's Against the Day: A Corrupted Pilgrim's Guide, edited by Jeffrey Severs and Christopher Leise, University of Delaware Press, 2011, pp. 191-213.

Bernays, Edward. Propaganda. Liveright, 1928.

Dos Passos, John. The Big Money. Signet Classics, 1969.

---. The $42^{\text {nd }}$ Parallel. Signet Classics, 1969.

---. Nineteen Nineteen. Signet Classics, 1969.

Gold, Michael. "The Education of John Dos Passos.” The English Journal, vol. 22, no. 2, 1933, pp. 87-97. JSTOR, JSTOR, www.jstor.org/stable/804561.

Ickstadt, Heinz. "History, Utopia and Transcendence in the Space-Time of Against the Day." Pynchon Notes, issue 54-55, 2008, pp. 216-44.

Krech, Shepard, III. “Bringing Linear Time Back In.” Ethnohistory, vol. 53, no. 3, 2006, pp. 567-93. EBSCOhost. search.ebscohost.com/login.aspx?direct=true $\& d b=$ mzh $\& A N=2007971051 \&$ site $=$ ehostlive \&scope $=$ site.

Laclau, Ernesto. New Reflections on the Revolution of Our Time. Verso, 1990.

Lesueur, Alexander A. Official Manual of the State of Missouri for the Years 1895-96. Tribune Printing Company, State Printers and Binders, Jefferson City, MO, 1895. 
Lukács, Georg. "Reification and the Consciousness of the Proletariat." History and Class Consciousness: Studies in Marxist Dialectics, translated by Rodney Livingstone, The MIT Press, 1971, pp. 83-222.

Magny, Claude-Edmonde. "Time in Dos Passos." Dos Passos: A Collection of Critical Essays, edited by Andrew Hook, Prentice-Hall, Inc., 1974, pp. 128-144.

Marx, Karl. Capital: A Critique of Political Economy Volume One. Translated by Ben Fowkes, Penguin, 1990.

Merck, Frederick, and Lois Bannister Merck. Manifest Destiny and Mission in American History: A Reinterpretation. Harvard University Press, 1963.

Piekarski, Krzysztof, Martin Kevorkian, and Elisabeth McKetta. "Mapping, the Unmappable, and Pynchon's Antitragic Vision." Pynchon's Against the Day: A Corrupted Pilgrim's Guide, edited by Jeffrey Severs and Christopher Leise, University of Delaware Press, 2011, pp. 47-66.

Pynchon, Thomas. Against the Day. Penguin, 2007.

Saltman, Richard B. The Social and Political Thought of Michael Bakunin. Greenwood Press, 1983.

Sartre, Jean-Paul “John Dos Passos and 1919.” Dos Passos: A Collection of Critical Essays, edited by Andrew Hook, Prentice-Hall, Inc., 1974, pp. 61-69.

Taylor, Frederick Winslow. The Principles of Scientific Management. Harper \& Brothers Publishers, 1919.

Terdiman, Richard. Present Past: Modernity and the Memory Crisis. Cornell University Press, 1993.

White, Hayden. The Content of the Form. The Johns Hopkins University Press, 1987. 
---. "The Structure of Historical Narrative." The Fiction of Narrative: Essays on History, Literature, and Theory 1957-2007, edited by Robert Doran, The Johns Hopkins University Press, 2010, pp. 112-125. 